\title{
PENGEMBANGAN APLIKASI MARKERLESS AUGMENTED REALITY LEGENDA ASAL MULA SELAT BALI
}

\author{
Gede Teddy Wirahardi Natha ${ }^{1}$, I Gede Mahendra Darmawiguna ${ }^{2}$, I Ketut Resika Arthana ${ }^{3}$ \\ 1,2,3 Jurusan Pendidikan Teknik Informatika FTK Undiksha \\ Universitas Pendidikan Ganesha \\ Singaraja-Bali, Indonesia
}

e-mail: teddy.wirahardi.natha@gmail.com, mahendra.darmawiguna@undiksha.ac.id, resika@undiksha.ac.id

\begin{abstract}
Abstrak
Penelitian ini dilakukan dengan tujuan untuk (1) merancang dan mengimplementasikan aplikasi Markerless Augmented Reality Legenda Asal Mula Selat Bali (2) mengetahui respon pengguna terhadap aplikasi Markerless Augmented Reality Legenda Asal Mula Selat Bali. Sudah saatnya kemajuan teknologi digunakan sebagai sarana untuk kembali membangkitkan kebudayaan Bali khususnya dalam hal cerita rakyat karena pelestarian kebudayaan dapat diupayakan dengan bantuan teknologi.

Penelitian ini menggunakan menggunakan proses R\&D (Riset and Development) dengan model ADDIE (Analysis Design Development Implementation Evaluate). Model ADDIE terdiri dari 5 tahapan, yaitu Analysis (Analisis), Design (Desain), Development (Pengembangan), Implementation (Implementasi) dan Evaluate (Evaluasi).

Hasil akhir penelitian ini berupa sebuah perangkat lunak aplikasi yang mampu dijalankan pada perangkat dengan system operasi android yaitu sebuah aplikasi markerless augmented reality dengan teknik user defined target (UDT) untuk menampilkan animasi 3 dimensi cerita Legenda Asal Mula Selat Bali lengkap dengan suara narasi cerita dalam Bahasa Indonesia dan Bahasa Inggris serta diiringi musik pengiring. Berdasarkan perhitungan yang dilakukan, aplikasi berada dalam kategori sangat baik dalam setiap pengujian. Berdasarkan hasil pengujian, aplikasi ini dapat diterapkan di lingkungan masyarakat agar dapat dijadikan sebagai media untuk memperkenalkan sekaligus melestarikan cerita rakyat Bali.
\end{abstract}

Kata-kata kunci: Android, Cerita Rakyat, Legenda Asal Mula Selat Bali, Markerless Augmented Reality, 3 Dimensi

\section{Abstract}

This research was conducted in order to (1) to design and implement applications Markerles Augmented Rality Legenda Asal Mula Selat Bali (2) determine the user response to the application of Markerles Augmented Rality Legenda Asal Mula Selat Bali. It is time that technological advances are used as a means to re-awaken the culture of Bali, especially in terms of folklore for the preservation of culture can be built with the help of technology.

This study uses using process $R \& D$ (Research and Development) with a model ADDIE (Analysis Design Development Implementation Evaluate). ADDIE Model consists of five phases, namely Analysis (Analysis), Design (Design), Development (development), Implementation (Implementation) and Evaluate (Evaluation).

The final result of this research is a software application that can run on devices with operating system Android is an application Markerless augmented reality techniques user defined targets (UDT) to display 3-dimensional animation stories Legend Origins Bali Strait complete with voice narration story in English Indonesian and English and accompanied by a musical accompaniment. Based on calculations performed, the application is in the excellent category in each test. Based on test results, this application can be applied in communities in order to serve as a medium to introduce and preserve the Balinese folklore. 
Keywords: Android, Folklore, Legenda Asal Mula Selat Bali, Markerless Augmented

Reality, 3 Dimension

\section{PENDAHULUAN}

Salah satu seni sastra adalah cerita rakyat. Menurut kamus besar Bahasa Indonesia, cerita rakyat merupakan cerita dari zaman dahulu yang hidup di kalangan rakyat dan diwariskan secara lisan. Dimana cerita rakyat merupakan golongan cerita yang hidup dan berkembang secara turun-temurun dari satu generasi ke generasi berikutnya. Cerita rakyat adalah bagian dari kekayaan budaya dan sejarah yang dimiliki setiap bangsa (Rosa, 2010). Ada banyak cerita rakyat yang ada di Bali misalnya seperti Cerita Kebo Iwa, Jayaprana dan Layonsari, Pan Balang Tamak, dan Manik Angkeran.

Dewasa ini cerita rakyat yang kaya akan pesan moral dan pembelajaran menjadi suatu hal yang kurang menarik bagi masyarakat. Hal ini tentunya disebabkan oleh beberapa faktor, seperti masuknya produk impor yang terus menggerus produk kebudayaan lokal itu sendiri.

Saat ini, anak-anak muda di Bali kurang tertarik pada mitos dan legenda karena mereka berpikir, bahwa mitos dan legenda tidak relevan di era globalisasi yang benar-benar up to date dan modern (Darmawiguna, 2015). Hal itu menguatkan bahwa dalam penyampaiannya, sebuah cerita hendaknya sejalan dengan perekembangan ilmu pengetahuan serta memanfaatkan kemajuan teknologi agar cerita rakyat Bali dapat disampaikan dengan lebih manarik sehingga anak-anak tidak cepat bosan dalam mencermati setiap isi dari cerita yang tertuang di dalamnya.

Salah satu wujud dari kemajuan teknologi yang dapat diterapkan saat ini adalah teknologi digital seperti Marlerless Augmented Reality (AR). Selain keuunggulannya untuk menampilkan objek maya ke dunia naya, teknologi AR juga dapat dikembangkan dalam berbagai platform contohnya android.

Dengan bantuan AR penulis bermaksud untuk membuat sebuah aplikasi yang dapat menampilkan animasi cerita rakyat dalam bentuk tiga dimensi ke dunia nyata. Cerita rakyat yang akan digunakan yaitu cerita Legenda Asal Mula Selat Bali.
Cerita Legenda Asal Mula Selat Bali memiliki banyak nilai moral yaitu janganlah kita menghambur-hamburkan uang dan berfoya-foya, ketamakan hanya akan merugikan diri sendiri dan orang lain, seorang anak harus berbakti kepada orang tua dan sebisa mungkin jangan menyusahkan dan mengecewakan orang tua.

Oleh karena itu penulis tertarik untuk mengembangkan cerita rakyat Legenda Asal Mula Selat Bali dalam bentuk penelitian yang berjudul Pengembangan Aplikasi Markerless Augmented Reality Legenda Asal Mula Selat Bali.

\section{KAJIAN TEORI}

\section{A. Cerita Rakyat}

Cerita rakyat bisa didefinisikan sebagai suatu bentuk karya sastra lisan yang lahir dan berkembang dari masyarakat tradisional yang disebarkan dalam bentuk relatif tetap dan di antara kolektif tertentu dari waktu yang cukup lama dengan menggunakan kata klise (Danandjaja, 2007).

\section{B. Augmented Reality}

Augmented Reality merupakan sebuah teknologi dengan memperkaya dunia nyata dengan menambahkan informasi digital dan media, seperti model 3D dan video, menampilkan secara realtime tampilan objek pada kamera smartphone, tablet, PC atau kacamata terhubung (Augment, 2015).

\section{Vuforia}

Vuforia merupakan Augmented Reality Software Development Kit yang membantu pengembang dalam menciptakan aplikasi Augmented Reality yang menggunakan teknologi computer vision yang berfokus pada pengenalan dan pelacakan gambar planar (Image Target). Versi vuforia yang sudah baik untuk digunakan dalam menciptakan aplikasi markerless augmented reality adalah vuforia versi 5.9 .9 dimana kelebihannya adalah animasi 3 dimensi yang ditampilkan akan lebih stabil. 


\section{Markerless Augmented Reality}

Salah satu metode Augmented Reality yang saat ini sedang berkembang adalah metode Markerless Augmented Reality, dengan metode ini pengguna tidak perlu lagi menggunakan sebuah marker untuk menampilkan elemen-elemen digital (Sanjani, 2015). Penggunaan teknik markerless akan lebih efisien karena tidak lagi menggunakan marker buku yang harus disiapkan sebelumnya. Hal itu menjadi nilai tersendiri dalam penggunaan aplikasi markerless augmented reality dengan teknik user definded target.

\section{METODOLOGI}

Pengembangan Aplikasi Markerless Augmentd Reality Legenda Asal Mula Selat Bali ini akan menggunakan metode penelitian pengembangan atau Research and Development (R\&D). Metode penelitian jenis ini merupakan metode penelitian yang digunakan untuk menghasilkan produk tertentu, dan menguji keefektifan produk tersebut (Sugiyono, 2010). Model yang digunakan adalah model ADDIE (Analysis Design Development Implementation Evaluate). Model ini merupakan model yang berlandasan pada pendekatan sistematis dimana peneliti dalam melakukan penelitiannya harus melakukan penelitian secara terstruktr dari satu tahap kemudian bernajut ke tahap selanjutnya tanpa melewati tahapan yang sudah ada sehingga model ini sangat efektif dan efisien serta prosesnya yang bersifat interaktif yakni hasil dari setiap tahap dapat digunakan di tahap berikutnya.

Model ADDIE pada pengembangan aplikasi Markerless Augmented Reality Legenda Asal Mula Selat Bali digambarkan pada gambar 1 .

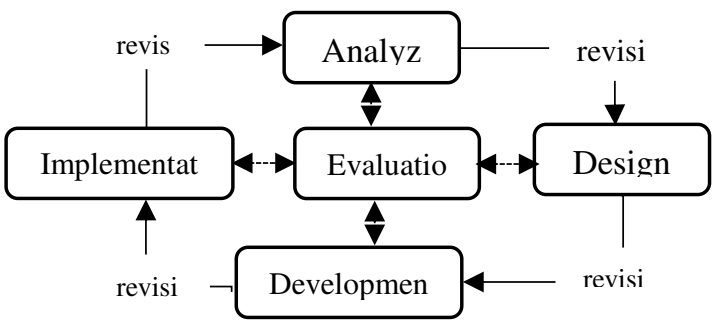

Gambar 1. Model ADDIE aplikasi

markerless augmented reality legenda asal mula selat bali
Pada metode ADDIE akan dilakukan evaluasi pada setiap tahapnya. Tahapan pertama yang dikerjakan peneliti adalah tahap analyze atau tahap analisis. Pada tahap analisis peneliti akan melakukan analisis permasalahan yang ada dengan cara mengumpulkan data dari buku, jurnal, dan penelitian yang pernah dilakukan sebelumnya yang berkaitan dengan pengembangan aplikasi berdasarkan pada cerita rakyat, mitos, dan legenda. Pada tahap ini juga dilakukan pencarian referensi mengenai teori-teori terkait yang diperlukan dan bagaimana menerapkannya dalam pengembangan sebuah aplikasi markerless augmented reality. Pada tahap ini dilakukan juga analisis terhadap kebutuhan fungsional dan non fungsional perangkat lunak. Evaluasi pada tahapan ini yaitu dilakukan dengan melihat kesesuaian kebutuhan aplikasi baik dari segi fungsional dan non fungsional jika hasil temuan pada tahap ini sudah memenuhi kebutuhan aplikasi, maka hasil dari tahap ini bisa digunakan sebagai panduan untuk tahapan berikutnya, misalnya melakukan evaluasi terhadap hasil analisis dari proses-proses yang akan berjalan pada aplikasi, apakah sudah sesuai dengan tujuan dan lingkungan penerapan dari aplikasi atau belum. Selain itu juga dilakukan analisis perangkat untuk penerapan aplikasi. Hasil dari evaluasi ini aplikasi akan berjalan pada perangkat android dengan minimal sistem operasi android 4.0.3.

Dalam pelaksanaannya, tahapan design akan menggunakan output dari tahap Analisis untuk merencanakan strategi untuk mengembangkan aplikasi seperti yang terlihat pada kebutuhan fungsional dan non fungsional. Selama tahap ini, peneliti menjelaskan bagaimana untuk mencapai tujuan instruksional yang ditentukan selama tahap Analisis. Pada tahap ini peneliti merancang sistem dengan use case, diagram activity, skenario, storyboard, disain karakter, dan rancangan antarmuka. Pada tahap ini dilakukan evaluasi yaitu menyesuaikan desain (use case, activity diagram karakter, antarmuka, dan storyboard) dengan kebutuhan perangkat lunak aplikasi yang sebelumnya sudah ditentukan sebelumnya pada tahap 
analisis baik dalam hal fungsional maupun non fungsional. Use case dan activity diagram harus sesuai dengan alur proses serta kebutuhan aplikasi, kemudian rancangan karakter dan storyboard harus sesuai dengan buku referensi cerita yang digunakan, serta rancangan antarmuka harus sesuai dengan kebutuhan aplikasi. Jika semua sudah terpenuhi, maka proses bisa dilanjutkan ke tahap berikutnya, jika belum sesuai maka tahap ini harus diulang dari awal. Output dari tahap desain menjadi masukan bagi tahap Development atau pengembangan.

Pengembangan adalah proses mewujudkan blueprint menjadi kenyataan. Satu langkah penting dalam tahap pengembangan adalah uji coba sebelum diimplementasikan. Pada tahap ini peneliti mengembangkan asset-aset yang diperlukan antara lain musik, efek suara, gambar, dan animasi. Pada tahap ini semua rancangan akan diwujudkan sehingga dapat digunakan sesuai dengan rancangan yang telah dibuat. Pada tahap ini juga dilakukan evaluasi, yaitu semua yang dihasilkan dari tahap ini harus sesuai dengan hasil yang didapatkan pada tahap desain baik dalam hal animasi, suara narasi, proses yang berjalan serta tampilan aplikasi. Jika hasil pengembangan sudah sesuai, maka proses bisa dilanjutkan, namun jika belum sesuai maka seluruh proses dalam tahap ini harus diulang hingga hasil yang didapat bisa sesuai.

Tahap Implementasi adalah tahap dimana aplikasi telah siap untuk diterapkan dan dilakukan pengujian kelayakan. Pengujian ini dilakukan dengan tujuan untuk memastikan aplikasi yang telah dibangun berdasarkan rancangan yang dibuat dan setiap fungsi yang terdapat pada aplikasi dapat berjalan dengan baik. Pada tahap ini dijelaskan lingkungan implementasi aplikasi. Pada tahap ini juga harus dilakukan evaluasi, yaitu untuk mengetahui kesesuaian hasil immplementasi dengan hasil pengembangan aplikasi. Evaluasi yang dilakukan adalah evaluasi white box, blackbox, kesesuaian proses, serta evaluasi penggunaan aplikasi pada lingkungan perangkat keras dan perangkat lunak yang berbeda. Pada tahap ini dilakukan pengujian source code dan fungsi-fungsi pada aplikasi apakah sudah berjalan dengan baik ataukah belum. Selain itu aplikasi juga diterapkan pada 5 perangkat android yang berbeda. Jika semua sudah berjalan dengan baik, maka aplikasi siap diterapkan ke lingkungan pengguna aplikasi namun jika belum maka perlu dilakukan perbaikan komponen aplikasi sesuai dengan kebutuhan.

Tahap evaluation merupakan tahap yang dilakukan untuk mengevaluasi proses pengembangan produk sesuai dengan model yang digunakan. Pada tahap ini hanya digunakan evaluasi formatif yang bertujuan untuk mengumpulkan data tentang efektivitas dan efisiensi aplikasi untuk mencapai tujuan yang ditetapkan. Data tersebut dimaksudkan untuk memperbaiki dan menyempurnakan aplikasi agar lebih efektif dan efisien. Evaluasi formatif terdiri dari pengujian uji ahli isi, ahli media, uji respon pengguna dan uji usability.

\section{HASIL DAN PEMBAHASAN}

Setelah penelitian selesai dilakukan, peneliti mendapatkan hasil penelitian sesuai dengan model yang digunakan. Adapun hasil penelitian dapat peneliti jabarkan pada setiap tahapan penelitian yang telah dikerjakan.

\section{A. Tahap Analyze (Analisis)}

Pada tahap ini akan dipaparkan mengenai hasil tahapan awal dari perangkat lunak yang akan dikembangkan, yaitu meliputi kebutuhan fungsional dan kebutuhan non fungsional.

\section{a. Kebutuhan fungsional}

Berdasarkan analisis terhadap proses - proses yang dapat diimplementasikan oleh Aplikasi Markerless Augmented Reality Legenda Asal Mula Selat Bali adalah sebagai berikut:

1. Aplikasi mampu menampilkan menu utama yang terdiri dari menu mulai, menu panduan, menu tentang, menu bahasa, dan menu keluar aplikasi.

2. Aplikasi dapat menampilkan cerita dalam bentuk 3D dengan karakter dan alur cerita sesuai dengan buku pedoman. 
3. Dalam menampilkan animasi 3D aplikasi bisa melakukan zoom in dan zoom out serta pergerakan rotasi objek.

4. Mampu menyajikan suara narasi penjelasan pada setiap bagian cerita (scene) sesuai dengan animasi 3 dimensi serta alur cerita.

5. Aplikasi dapat menggunakan 2 bahasa, yaitu Bahasa Indonesia dan Bahasa Inggris.

6. Aplikasi dapat memperdengarkan suara narasi dalam Bahasa Indonesia dan Bahasa Inggris disertai musik pengiring animasi $3 \mathrm{D}$.

7. Aplikasi dapat menampilkan popup adegan cerita.

8. Aplikasi dapat menampilkan panduan pengunaan serta informasi tantang aplikasi.

9. Aplikasi dapat menampilkan popup dialog saat animasi selesai.

b. Kebutuhan non fungsional

Berdasarkan analisis dalam pembuatan aplikasi Markerless Augmented Reality Legenda Asal Mula Selat Bali, maka didapatkan kebutuhan non fungsional dari aplikasi ini adalah sebagai berikut.

\section{Usability}

Pengembangan teknologi Markerless Augmented Reality Legenda Asal Mula Selat Bali ini dibuat sebagai media belajar yang bersifat multimedia interaktif yang dapat digunakan dengan mudah yaitu dengan menggunakan animasi berbentuk 3D serta pengguna dapat melakukan interaksi dengan aplikasi saat aplikasi dijalankan. Selain itu tampilan multimedia yang dirancang memiliki fungsi untuk menginformasikan pesan dan memiliki interaktivitas kepada penggunanya. Pada aspek usability, aplikasi diharapkan mampu memenuhi lima komponen yang ditetapkan yaitu tingkat kemahiran pengguna (learnability), tingkat efisiensi (efficiency), tingakat kesalahan dalam penggunaan aplikasi (error), tingkat kemampuan pengguna dalam mengingat fitur dan fungsi tombol yang ada pada aplikasi (memorability), serta yang terakhir adalah tingkat kepuasan pengguna dalam menggunakan aplikasi (statisfaction).

\section{Compatibility}

Aplikasi Markerless Augmented Reality Legenda Asal Mula Selat Bali ini dapat dijalankan pada sistem operasi android minimal versi 4.0.3. Hal ini dikarenakan untuk vuforia dimana perangkat phone dan tablet yang suport adalah perangkat dengan sistem operasi android minimal versi 4.0.3 serta versi selanjutnya (Vuforia, 2016). Selain itu, aplikasi ini akan dapat berlajan optimal pada hardwere dengan RAM minimal 1GB, dikarenakan aplikasi harus memuat objek animasi 3 dimensi dengan ukuran yang cukup besar sehingga akan membutuhan ruang pemrosesan yang besar pula. Dari hasil evaluasi pada tahap analisis, semua hasil dari tahap analisis sudah sesuai dengan tujuan dibuatnya aplikasi.

\section{B. Design (Perancangan)}

a. Rancangan use case diagram

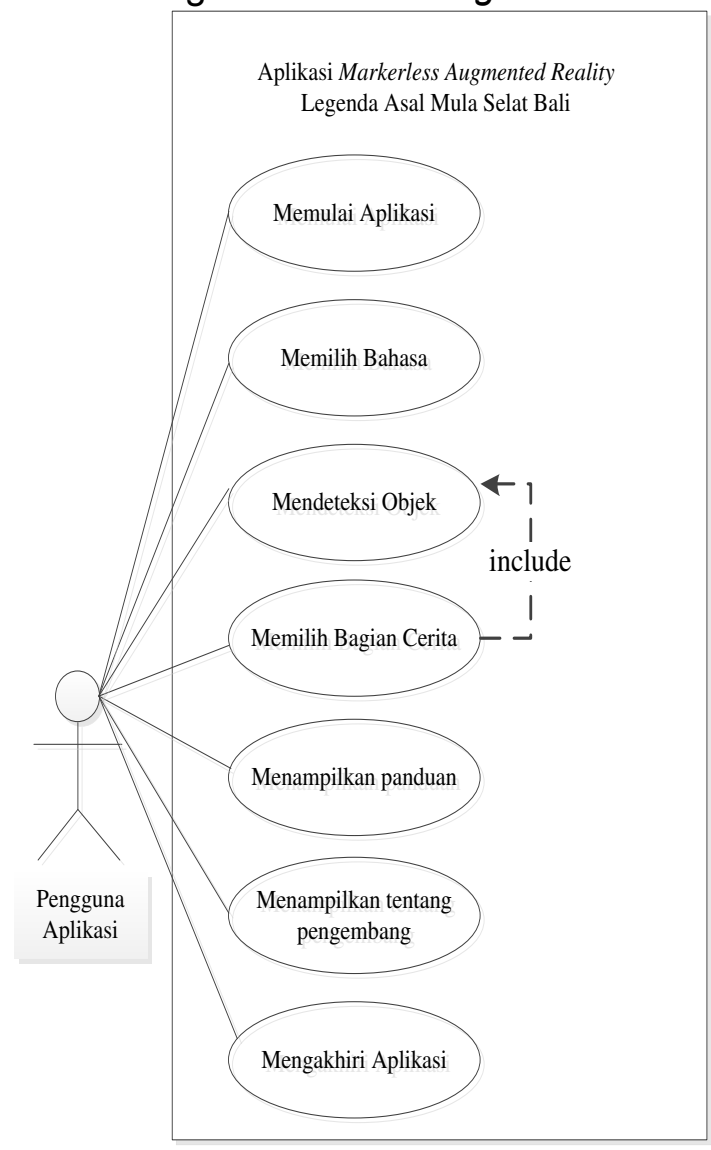

Gambar 2. Use case diagram aplikasi markerless augmented reality legenda asal mula selat bali 
Use Case Diagram dapat menggambarkan fungsionalitas yang akan berjalan pada sistem yang akan dibuat. Hal ini memberi gambaran pada kebutuhan sebuah aplikasi yang dibuat jika dilihat dari sudut pandang pengguna. Sehingga dalam merancang aplikasi akan sesuai dengan fitur-fitur yang dapat dilakukan oleh pengguna aplikasi. Use Case Diagram dari Aplikasi Markerless Augmented Reality Legenda Asal Mula Selat Bali adalah seperti pada Gambar 2. Jika dilihat pada Gambar 2, aplikasi ini mempunyai beberapa fitur yang mendukung dalam pengunaan aplikasi dan fitur yang paling penting adalah aplikasi dapat menampilkan cerita rakyat dalam bentuk animasi tiga dimensi yang disertai dengan suara narasi dan musik pengiring animasi. Aplikasi juga memberikan keleluasaan bagi pengguna dalam menggunakan aplikasi yaitu pengguna bisa memilih sendiri bagian cerita yang ingin ditampilkan.

Tabel 1. Skenario Aplikasi Markerless Augmented Reality Legenda Asal Mula Selat Bali

\begin{tabular}{|c|c|}
\hline Tahap & Penjelasan \\
\hline 1 & User memulai aplikasi \\
\hline 2 & $\begin{array}{l}\text { User memilih bahasa yang ingin } \\
\text { digunakan. }\end{array}$ \\
\hline 3 & $\begin{array}{l}\text { Saat berada pada layar utama } \\
\text { aplikasi, user dapat melakukan } \\
\text { pendeteksian objek untuk } \\
\text { menampilkan animasi objek 3D } \\
\text { cerita Legenda Asal Mula Selat } \\
\text { Bali beserta narasi. }\end{array}$ \\
\hline 4 & $\begin{array}{l}\text { User dapat memilih adegan cerita } \\
\text { yang diinginkan. }\end{array}$ \\
\hline 5 & $\begin{array}{l}\text { User memilih menampikan } \\
\text { panduan maka akan ditampilkan } \\
\text { informasi cara menggunakan } \\
\text { aplikasi. }\end{array}$ \\
\hline 6 & $\begin{array}{l}\text { User memilih menampilkan } \\
\text { tentang pengembang maka akan } \\
\text { ditampilkan informasi seputar } \\
\text { pengembang aplikasi. }\end{array}$ \\
\hline 7 & User mengakhiri aplikasi \\
\hline
\end{tabular}

Dari hasil evaluasi pada tahap desain, rancangan yang dihasilkan sudah sesuai dengan hasil dari tahap analisis dan sudah mampu memenuhi kebutuhan aplikasi.

b. Rancangan activity diagram

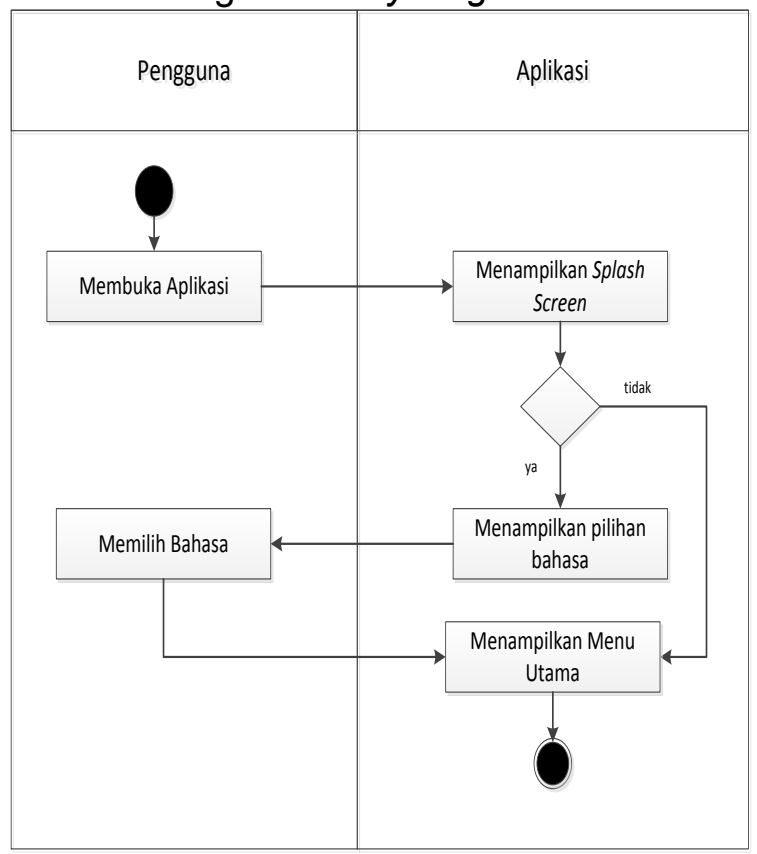

Gambar 3. Activity diagram memulai aplikasi

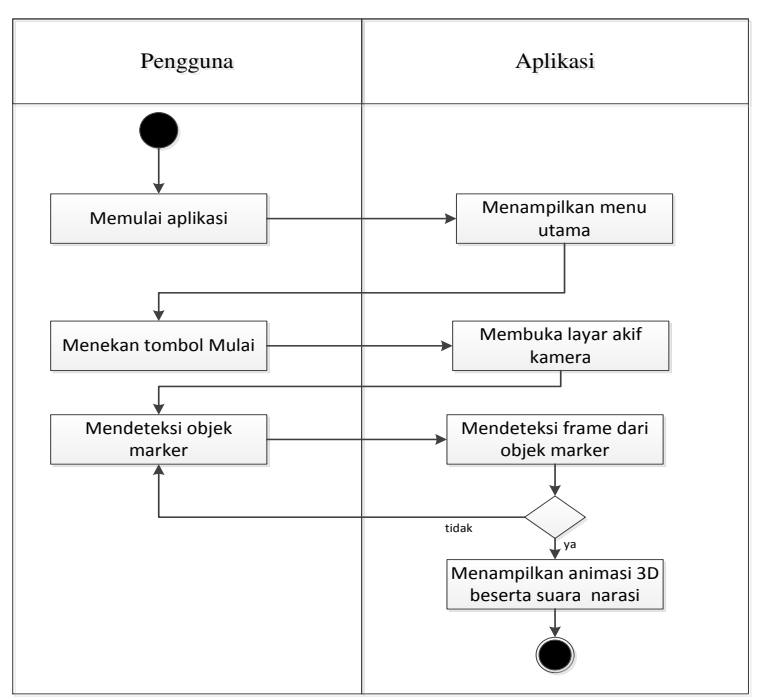

Gambar 4. Activity diagram mendeteksi objek 


\section{Development (Pengembangan)}

1. Layar Antarmuka Perangkat Lunak Rancangan layar antarmuka perangkat lunak Markerless Augmented Reality Legenda Asal Mula Selat Bali dapat dikembangkan menggunakan fitur yang terdapat pada Unity 3D dengan berpedoman pada rancangan antarmuka yang telah dirancang sebelumnya. Dalam pengembangan tampilan antarmuka aplikasi dilakukan agar memiliki kesesuaian dengan pedoman yaitu rancangan antarmuka yang telah dibuat sebelumnya pada tahap desain.

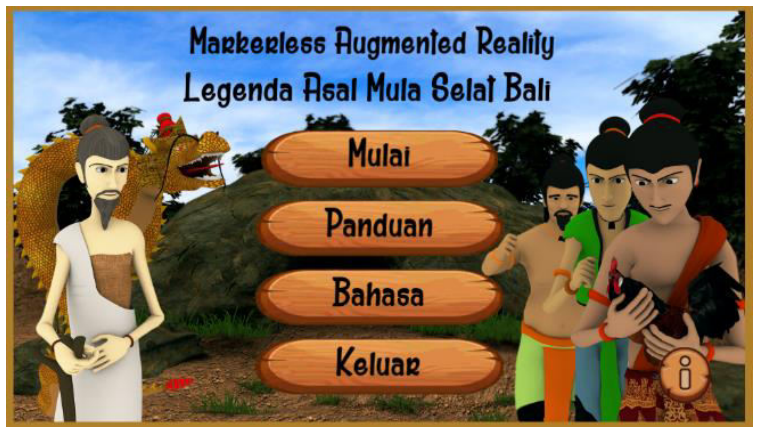

Gambar 5. Tampilan menu utama

Pada tampilan menu utama ini dikembangkan dengan menggunakan aplikasi Adobe Photoshop CS6 sehingga bisa terlihat seperti pada gambar 3. Tombol utama pada menu ditambahkan teks yang dimaksudkan untuk memudahkan pengguna dalam melakukan interaksi dengan aplikasi. Tombol Tentang dibuat berbeda karena untuk menyesuaikan layout menu utama dan tetap menggunakan tombol yang sudah umum digunakan.

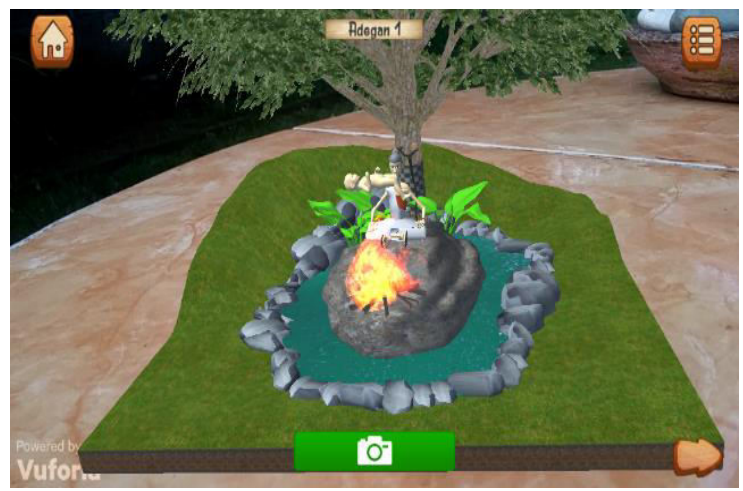

Gambar 6. Tampilan adegan 1
Tampilan adegan merupakan untuk menampilkan setiap adegan yang ada pada aplikasi ini. Pada tampilan ini terdapat tombol popup untuk memilih adegan secara acak, tomboh home untuk kembali ke menu utama, dan tombol next untuk menujuu adegan berikutnya. Animasi 3 dimensi akan muncul jika pengguna sudah berhasil mendeteksi objek yang digunakan sebagai marker. Tampilan adegan dirancang secara konsisten mulai dari adegan 1 hingga adegan terakhir baik dari penempatan tombol serta desain yang tampilannya dengan tujuan lebih memudahkan pengguna dalam menggunakan aplikasi. Pengembangan tampilan ini menggunakan Unity 3D sehingga bisa dilihat pada gambar 7.

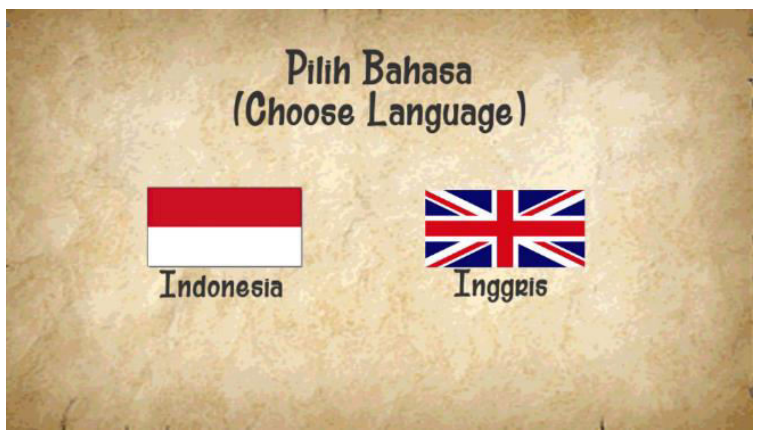

Gambar 7. Tampilan Pilih Bahasa

Memilih Bahasa adalah salah satu fitur penting dalam aplikasi ini dimana pengguna bisa memilih satu dari dua Bahasa yaitu Bahasa Inonesia dan Bahasa Inggris. Jika pengguna memilih tombol Bahasa Indosesia, maka aplikasi akan menggunakan Bahasa Indonesia, namun jika pengguna memilih tombol Bahasa Inggris, maka aplikasi akan menggunakan Bahasa Inggris. Penggunaan tombol ditambahkan image bendera dengan maksud agar memudahkan pengguna dalam menafsirkan fungsi dari tombol pilih Bahasa.

Dari hasil evaluasi tahap pengembangan, aplikasi Markerless Augmeted Reality Legenda Asal Mula Selat Bali sudah sesuai dengan rancangan yang sudah dibuat pada tahap desain sehingga dapat diterapkan pada tahap implementasi.

\section{Implementation (Implementasi)}


Pada tahap implementation (implementasi), hasil aplikasi yang telah dikembangkan diuji cobakan dan diterapkan pada pengguna untuk diuji.

1. Pengujian White Box

Pengujian whitebox dilakukan dengan cara mengecek semua Source Code untuk memastikan tidak ada error. Pada aplikasi Markerless Augmented Reality Legenda Asal Mula Selat Bali akan dilakukan pengujian terhadap file-file utama yang menjadi inti proses dalam aplikasi yang dikembangkan. Dari hasil pengujian, semua source code yang digunakan pada aplikasi sudah dapat berjalan dengan baik tanpa terjadi error.

\section{Pengujian Black Box}

$$
\text { Bertujuan untuk mengetahui }
$$

kebenaran proses sesuai dengan teknik User Defined Target (UDT) yang ada pada aplikasi Markerless Augmented Legenda Asal Mula Selat Bali. Penguji akan diberikan angket setelah menggunakan aplikasi. Pengujian akan dilakukan oleh satu orang mahasiswa Pendidikan Teknik Informatika Undiksha dimana penguji menggunakan aplikasi Markerless Augmented Reality Legenda Asal Mula Selat Bali dengan mencoba semua proses yang ada pada aplikasi mulai dari proses mulai saat aplikasi mulai dijalankan hingga proses keluar dari aplikasi. Dari hasil pengujian, semua fungsi dan fitur yang terdapat pada aplikasi sudah dapat berfungsi dengan baik sesua dengan rancangan yang dibuat.

\section{Pengujian pada perangkat yang berbeda}

Aplikasi diuji untuk pada 5 jenis hardware (smartphone android) berbeda yaitu smartphone Xiaomi Redmi Note 2, smartphone Opoo Neo 7, smartphone Asus Zenfone 5, smartphone Vivo Y51L, dan perangkat smartphone Samsung Galaxy Grand 2. Dari hasil pengujian, aplikasi dapat berjalan dengan baik.

\author{
E. Evaluation (Evaluasi) \\ 1. Pengujian Ahli Isi \\ Setelah dilakukan pengujian, \\ selanjutnya dilakukan analisis data dari \\ hasil pengujian ahli isi. Berdasarkan
}

penilaian dari ahli isi, dapat dianalisa ratarata persentase keseluruhan penilaian yaitu $80 \%$, aplikasi Markerless Augmented Reality Legenda Asal Mula Selat Bali berada dalam kriteria sangat baik. Hasil perhitungan dapat dilihat pada tabel 2 .

\section{Pengujian Ahli Media \\ Berdasarkan penilaian dari ahli} media, maka dapat dianalisa rata-rata persentase keseluruhan penilaian yaitu 95.00\%. Aplikasi Markerless Augmented Reality Legenda Asal Mula Selat Bali berada dalam kriteria sangat baik. Hasil perhitungan dapat dilihat pada tabel 3 .

3. Pengujian Usability

Dari hasil analisis uji usability diketahui bahwa aplikasi Markerless Augmented Reality Legenda Asal Mula Selat Bali masuk ke dalam kriteria sangat baik dan sesuai dengan harapan peneliti. Berdasarkan hasil pengujian maka didapatkan tingkat learnability aplikasi berada pada kategori sangat baik. Hal ini menggambarkan bahwa secara keseluruhan pengguna yang menggunakan aplikasi Markerless Augmented Reality Legenda Asal Mula Selat Bali merasa cepat dalam menguasai aplikasi sehingga pengguna tidak perlu lagi selalu melihat panduan sebelum menggunakan aplikasi. Dengan mahirnya pengguna aplikasi dalam menggunakan aplikasi, maka akan timbul kenyamanan dan kemudahan dalam menggunakan aplikasi ini. Nilai terendah dalam komponen learnability adalah 3 yaitu diberikan oleh 2 dari 10 orang responden pada butir pernyataan nomor 3 yaitu pada cara untuk menampilkan objek animasi 3 dimensi. Hal ini dikarenakan teknik penyampaian animasi 3 dimensi dengan metode markerless augmented reality masih merupakan teknologi baru di kalangan masyarakat. Untuk menanggapi keadaan ini, peneliti menambahkan lagi panduan penggunaan untuk memperjelas cara menampilkan objek animasi 3 dimensi seperti menampilkan lebih detail syaratsyarat objek yang bisa digunakan sebagai marker serta posisi yang benar saat melakukan dekteksi marker.

Tingkat efficiency aplikasi Markerless Augmented Reality Legenda Asal Mula Selat Bali secara keseluruhan juga sudah 
sangat baik dengan presentase $84.5 \%$. Namun komponen ini menjadi komponen dengan presentase paling rendah dari keseluruhan 5 komponen dalam uji usability yang dilakukan peneliti. Hal ini dikarenakan 4 dari 10 orang memberikan nilai 2 pada butir pernyataan nomor 6 yaitu mengenai kemudahan dalam menampilkan objek animasi 3 dimensi. Ini dapat terjadi karena dalam penggunaan aplikasi Markerless Augmented Reality harus dilakukan dengan cara yang benar dan sesuai dengan panduan yang telah diberikan agar aplikasi bisa berjalan sesuai fungsinya. Responden yang kesulitan dalam menampilkan objek animasi 3 dimensi dikarenakan masih belum terbiasa untuk menggunakan aplikasi markerless augmented reality. Hal ini menjadi kendala utama pada setiap aplikasi yang menggunakan metode markerless augmented reality. Namun peneliti sudah meminimalisir keadaan ini dengan menyimpan satu marker yang di deteksi oleh aplikasi, sehingga jika kamera keluar dari are marker maka pengguna bisa mengarahkan kamera ke area marker sebelumnya dan animasi 3 dimensi akan kembali dilanjutkan tanpa melakukan deteksi ulang. Dengan adanya evaluasi komponen efficiency ini, diharapkan bisa menjadi panduan bagi peneliti yang akan melakukan penelitian sejenis kedepannya.

Komponen ketiga ada memorability atau tingkat kemudahan dalam mengingat fitur yang ada pada aplikasi. Dari hasil yang diperoleh, aplikasi Markerless Augmented Reality Legenda Asal Mula Selat Bali sudah sangat baik. Ini dikarenakan peneliti membuat fitur dan tombol pada aplikasi menjadi lebih sederhana agar mudah diingat. Misalnya dalam aplikasi peneliti hanya menggunakan kurang lebih 4 jenis tombol yang sudah umum digunakan dengan masing-masing tombol mempunyai satu fungsi tersendiri. Selain itu untuk menghindari perbedaan penafsiran fungsi tombol aplikasi, maka peneliti juga menambahkan teks dan gambar pada tombol yang dianggap penting.

Selanjutnya komponen error adalah komponen yang penting dalam uji usability. Pada aplikasi Markerless Augmented Reality Legenda Asal Mula Selat Bali pengguna hampir tidak menemukan error baik pada fitur ataupun tombol yang disediakan sehingga komponen ini masuk ke dalam kategori sangat baik. Hasil ini bisa terwujud karena peneliti sudah melakukan pengujian yang serius pada tahap pengujian white box dan black box sehingga saat aplikasi diimplementasikan di lapangan, tingkat error bisa diminimalisir bahkan dihilangkan.

Komponen terakhir adalah tingkat statisfaction atau kepuasan pengguna dalam menggunakan aplikasi. Dari hasil yang diperoleh, tingkat kepuasan pengguna pada aplikasi Markerless Augmented Reality Legenda Asal Mula Selat Bali sudah sangat baik. Ini dikarenakan teknik penyampaian materi dengan teknik markerless augmented reality sangat menarik, selain itu fitur dan tombol yang disediakan sudah berjalan tanpa adanya error, serta kejelasa tampilan animasi seta suara narasi menjadi poin penting dalam kepuasan pengguna, terbukti hamper semua responden memberikan nilai 5 pada poin-poin tersebut.

Dari hasil uji usability, secara keseluruhan aplikasi Markerless Augmented Reality Legenda Asal Mula Selat Bali memiliki rerata dengan prentase $92.14 \%$ yang masuk ke dalam kategori sangat baik sehinga peneliti tidak melakukan revisi terhadap aplikasi ini. Selain itu aplikasi Markerless Augmented Legenda Asal Mula Selat Bali tersebut sebelumnya sudah diuji oleh ahli isi dan ahli media. Hasil perhitungan dapat dilihat pada tabel 4 .

Tabel 2. Hasil perhitungan usability

\begin{tabular}{|c|c|c|c|c|}
\hline No & $\begin{array}{l}\text { Pernyat } \\
\text { aan }\end{array}$ & Skor & $\begin{array}{c}\text { Presentase } \\
(\%)\end{array}$ & $\begin{array}{c}\text { Kateg } \\
\text { ori }\end{array}$ \\
\hline 1 & $\begin{array}{l}\text { Learnab } \\
\text { ility }\end{array}$ & 237 & $94.8 \%$ & $\begin{array}{l}\text { Sanga } \\
\text { t Baik }\end{array}$ \\
\hline 2 & $\begin{array}{l}\text { Efficienc } \\
y\end{array}$ & 169 & $84.5 \%$ & Baik \\
\hline 3 & $\begin{array}{l}\text { Memora } \\
\text { bility }\end{array}$ & 89 & $89 \%$ & $\begin{array}{l}\text { Sanga } \\
\text { t Baik }\end{array}$ \\
\hline 4 & Error & 247 & $98.8 \%$ & $\begin{array}{l}\text { Sanga } \\
\text { t Baik }\end{array}$ \\
\hline 5 & $\begin{array}{l}\text { Statisfac } \\
\text { tion }\end{array}$ & 234 & $93.6 \%$ & $\begin{array}{l}\text { Sanga } \\
\text { t Baik }\end{array}$ \\
\hline \multicolumn{3}{|c|}{ Rata-rata presentase } & $92.14 \%$ & $\begin{array}{l}\text { Sanga } \\
\text { t Baik }\end{array}$ \\
\hline
\end{tabular}

4. Pengujian Respon Pengguna 


\begin{abstract}
Dari hasil analisis uji respon pengguna diketahui bahwa aplikasi Markerless Augmented Reality Legenda Asal Mula Selat Bali masuk ke dalam kriteria sangat baik dengan rerata persentase dari 10 subyek (butir) penilaian yaitu $90.80 \%$. Dengan demikian dapat disimpulkan aplikasi ini sudah dapat diterima di kalangan masyarakat dan dapat digunakan sesuai dengan fungsinya.

Tabel 3. Hasil perhitungan ahli isi
\end{abstract}

\begin{tabular}{|c|c|c|c|c|}
\hline No & Item Pernyataan & $\begin{array}{l}\text { Skor } \\
\text { Penguji }\end{array}$ & PP (\%) & Kategori \\
\hline \multicolumn{5}{|c|}{ Pembelajaran } \\
\hline 1 & $\begin{array}{l}\text { Isi Aplikasi Markerless Augmented Reality Legenda Asal } \\
\text { Mula Selat Bali dapat digunakan untuk melestarikan cerita } \\
\text { rakyat. }\end{array}$ & 4 & $80.00 \%$ & Sangat Baik \\
\hline 2 & $\begin{array}{l}\text { Isi aplikasi sudah sesuai dengan buku yang berjudul } \\
\text { Siddhimantra Tatwa yang diterbitkan oleh Mahakertawarga } \\
\text { DBMAS Pusat Provinsi Bali Tahun } 2008\end{array}$ & 4 & $80.00 \%$ & Sangat Baik \\
\hline \multicolumn{5}{|c|}{ Isi Materi dari Aplikasi } \\
\hline 3 & $\begin{array}{l}\text { Isi materi aplikasi sudah sesuai dengan buku yang berjudul } \\
\text { Siddhimantra Tatwa yang diterbitkan oleh Mahakertawarga } \\
\text { DBMAS Pusat Provinsi Bali Tahun } 2008 \text {. }\end{array}$ & 4 & $80.00 \%$ & Sangat Baik \\
\hline 4 & $\begin{array}{l}\text { Pergerakan animasi sudah sesuai dengan jalannya cerita } \\
\text { Legenda Asal Mula Selat Bali yang terdapat dalam buku } \\
\text { yang berjudul Siddhimantra Tatwa yang diterbitkan oleh } \\
\text { Mahakertawarga DBMAS Pusat Provinsi Bali Tahun } 2008 \text {. }\end{array}$ & 4 & $80.00 \%$ & Sangat Baik \\
\hline \multicolumn{5}{|c|}{ Pemakaian Kata dan Bahasa } \\
\hline 5 & Menggunakan huruf/karakter yang sesuai. & 4 & $80.00 \%$ & Sangat Baik \\
\hline 6 & $\begin{array}{l}\text { Aplikasi yang sudah dibuat menggunakan bahasa Indonesia } \\
\text { yang baik dan benar }\end{array}$ & 4 & $80.00 \%$ & Sangat Baik \\
\hline 7 & $\begin{array}{l}\text { Aplikasi yang sudah dibuat menggunakan bahasa Inggris } \\
\text { yang baik dan benar }\end{array}$ & 4 & $80.00 \%$ & Sangat Baik \\
\hline \multicolumn{3}{|c|}{ Total Rata-Rata Persentase } & $80.00 \%$ & Sangat Baik \\
\hline
\end{tabular}

Tabel 4. Hasil perhitungan ahli media

\begin{tabular}{|c|c|c|c|c|c|c|}
\hline No & Item Pernyataan & $\begin{array}{c}\text { Skor } \\
\text { Penguji } \\
1\end{array}$ & $\begin{array}{c}\text { Skor } \\
\text { Penguji } \\
2\end{array}$ & Skor & PP (\%) & Kategori \\
\hline 1 & $\begin{array}{l}\text { Kejelasan suara narasi dalam AR } \\
\text { Legenda Asal Mula Selat Bali }\end{array}$ & 5 & 5 & 10 & $100.00 \%$ & Sangat Jelas \\
\hline 2 & Kesesuaian musik (back sound) & 4 & 4 & 8 & $80.00 \%$ & $\begin{array}{l}\text { Sangat } \\
\text { Sesuai }\end{array}$ \\
\hline 3 & Ketepatan pemilihan jenis huruf & 4 & 4 & 8 & $80.00 \%$ & Sangat Tepat \\
\hline 4 & Ketepatan pemilihan ukuran huruf & 4 & 4 & 8 & $80.00 \%$ & Sangat Tepat \\
\hline 5 & $\begin{array}{l}\text { Kesesuaian komposisi warna huruf } \\
\text { dengan warna latar (background) }\end{array}$ & 5 & 5 & 10 & $100.00 \%$ & Sangat Tepat \\
\hline 6 & Keterbacaan objek 3D & 5 & 5 & 10 & $100.00 \%$ & Sangat Tepat \\
\hline 7 & $\begin{array}{l}\text { Kesesuaian ukuran menu pada } \\
\text { layar smartphone/tab }\end{array}$ & 5 & 5 & 10 & $100.00 \%$ & $\begin{array}{l}\text { Sangat } \\
\text { Sesuai }\end{array}$ \\
\hline 8 & $\begin{array}{l}\text { Kemenarikan tampilan AR } \\
\text { Legenda Asal Mula Selat Bali }\end{array}$ & 5 & 4 & 9 & $90.00 \%$ & $\begin{array}{l}\text { Sangat } \\
\text { Menarik }\end{array}$ \\
\hline 9 & $\begin{array}{l}\text { Kejelasan petunjuk penggunaan } \\
\text { AR Legenda Asal Mula Selat Bali }\end{array}$ & 5 & 5 & 10 & $100.00 \%$ & Sangat Jelas \\
\hline 10 & $\begin{array}{l}\text { Kemudahan memilih menu AR } \\
\text { Legenda Asal Mula Selat Bali }\end{array}$ & 5 & 5 & 10 & $100.00 \%$ & Sangat mudah \\
\hline
\end{tabular}


adegan, aplikasi dapat melakukan rotasi dan zoom in zoom out pada objek yang ditampilkan. Respon yang diperoleh dari ahli isi adalah aplikasi Markerless Augmented Reality Legenda Asal Mula Selat Bali masuk ke dalam kategori sangat baik dengan rata-rata persentasi penilaian $80 \%$. Hasil dari pengujian ahli media dapat dilihat bahwa aplikasi layak uji coba lapangan dengan revisi dan sesuai saran yang diberikan dengan rata-rata persentasi penilaian $95.00 \%$ yaitu masuk ke dalam kategori sangat baik. Pada Pengujian untuk mengetahui respon pengguna, aplikasi Markerless Augmented Reality Legenda Asal Mula Selat Bali masuk ke dalam kriteria sangat baik dengan rerata persentase dari 10 subyek (butir) penilaian yaitu $90.80 \%$. Selain itu, hasil pengujian tingkat usability, aplikasi ini mempunyai tingkat usability sangat baik dengan rerata presentase yaitu sebesar $92.14 \%$.

Berdasarkan hasil penelitian pengembangan dan kesimpulan, dapat disarankan bagi pembaca yang ingin mengembangkan sistem ini sebagai berikut: (1) animasi agar lebih baik dari sebelumnya. (2) lebih memperhatikan ukuran dari aplikasi (3) diharapkan untuk pengembangan selanjutnya dapat menampilkan kualitas penanda sebelum menampilkan objek 3 dimensi. (4) Untuk pengembangan berikutnya diharapkan aplikasi dapat melakukan pendeteksian objek yang dideteksi dari berbagai sudut namun tetap dapat menampilkan posisi objek 3 dimensi yang baik agar dapat meningkatkan efisiensi dalam penggunaan aplikasi khususnya aplikasi yang menggunakan teknik mrkerless user definded target.

\section{DAFTAR PUSTAKA}

Augment. (2015, Desember 22). How augmented reality works. Retrieved Desember 22, 2015, from Augmentdev: http://www.augmentedev.com/howaugmented-reality-works/

Danandjaja, J. (2007). Folklor Indonesia, IImu Gosip, Dongeng, dan Lain-lain. Jakarta: Pustaka Utama Grafiti.

Darmawiguna, I. G. (2015). The Augmented Reality Story Book Project: A colection of Balinese Miths and Legend. Springer Internetional Publishing Switzerland, Volume 9254 of the series Lecture Notes in Computer Science, 71-88.

Rosa, D. (2010). Cerita Rakyat 33 Provinsi dari Aceh Sampai Papua. Jakarta Selatan: TransMedia Pustaka.

Sanjani, D. A., Crisnapati, P. N., Wirawan, I. M., \& Darmawiguna, I. G. (2015). Pengembangan Aplikasi Pengenalan Gedung Universitas Pendidikan Ganesha Berbasis Markerless Augmeted Reality. Kumpulan Artikel Mahasiswa Pendidikan Teknik Informatika (KARMAPATI) Volume 4, Nomor $1,9$.

Sugiyono. (2010). Metode Penelitian Pendidikan: Pendekatan Kuantitatif, Kualitatif, dan $R$ \& $D$. Bandung: Alfabeta.

Vuforia. (2016, 10 22). Vuforia Supported Versions. Retrieved from Vuforia Developer Library: https://library.vuforia.com/articles/Solu tion/Vuforia-Supported-Versions 